DOI: 10.17707/AgricultForest.65.1.18

\author{
Tatjana ŽDRALIĆ, \\ Miroslav LALOVIĆ, Jelena NIKITOVIĆ ${ }^{1}$
}

\title{
THE CORRELATIVE RELATIONSHIP OF THE MASS EGSS AND TRAITS OF EGGS QUALITY OF LIGHT LINE HYBRIDS
}

\begin{abstract}
SUMMARY
Although the production traits are still considered to be the main indicators for calculating the production index, producers must increasingly take into account the quality of eggs in order to meet consumer demand. The quality of eggs is becoming an important factor, largely depending on the placement of products on the market, and therefore the economic success of production. This means that special attention should be paid to the quality of eggs (egg height, length and width of the egg, egg shape index, cleanliness and color of the shell, color of the yolk).

Therefore, the work placed emphasis mutual correlation connections and dependencies between ground balls and qualities with light line hybrid Isa Brown, during three age periods of laying hens.

By monitoring these indicators and determining the correlation connection between these characteristics make it possible to better assessment of expression of genetic potential of the respective hybrids on a private farm near Sarajevo, Bosnia and Herzegovina.
\end{abstract}

Keywords: phenotipic correlation, mass of egg, traits of egg quality, Isa Brown.

\section{INTRODUCTION}

The quality of eggs is becoming an important factor, largely depending on the placement of products on the market, and therefore the economic success of production.

According to Schwaegele (2001), the quality of eggs is a set of all the features that are significant for the use of eggs as a foodstuff. One should not forget that the last link in the consumer egg production chain is the consumer, and the fact that the success of the production depends on the attitude of the consumer towards a product, then the definition of a quality egg is that the eggs that consumers prefer are the best (Pavlovski, 1988). Although production traits still consider basic indicators for the calculation of production index, but

\footnotetext{
${ }^{1}$ Tatjana Ždralić, (corresponding author: tatjana.zdralic@gmail.com), Miroslav Lalović, University of East Sarajevo, Faculty of Agriculture, East Sarajevo, BOSNIA AND HERZEGOVINA; Jelena Nikitović, University of Banja Luka, Faculty of Agriculture, Institute for genetics resources, Banja Luka, BOSNIA AND HERZEGOVINA

Notes: The authors declare that they have no conflicts of interest. Authorship Form signed online.
} 
producers must increasingly take into account the quality of the eggs, to meet the demands of consumers.

This means that special attention should be paid to the quality of eggs (egg height, length and width of the egg, egg shape index, cleanliness and color of the shell, color of the yolk).

Campo et al. (2007), Zita et al. (2009) found that the quality of the eggs in addition to genotype affects the age of hens. The authors conclude that regardless of genetic origin, the mass of eggs increases with the age of laying hens.

Contrary to previous authors Zemková et al. (2007) states that the age of the laying hens does not statistically influence the mass of the eggs.

Van den Brand et al. (2004) point out that the age of the laying hens affects the reduction in egg shape index.

Tolimir et al. (2008), on the basis of the results of the experiment in which they examined the influence of genotype and age on egg quality traits such as egg mass, index of shape and cleanliness of the shell, found that the genotype did not have any influence on any of the investigated traits. On the other hand, statistical significance was confirmed by the influence of age on the egg index alone. The values for the egg-shaped index were reduced with age (it was $82,10 \%$ at 31 weeks, from 44 weeks $82,23 \%$ and from 68 weeks $76,70 \%$ ).

The aim of this paper was to determinate and test the phenotypic correlation between eggs mass and traits of egg quality (egg lenght, width of the egg, egg shape index, cleanliness egg, colour of the shell, colour of the yolk) in three production stages - Ages of Laying Hens $\left(\mathrm{ALH}_{20}, \mathrm{ALH}_{28}, \mathrm{ALH}_{48}\right)$, with a light line hybrid Isa Brown.

By monitoring these indicators and determining the correlation connection between these traits give the better possibility to evaluate expression of genetic potential light line hybrid Isa Brown on a private farm near Sarajevo, Bosnia and Herzegovina.

\section{MATERIAL AND METHODS}

Laying light line hybrid Isa Brown hybrid bred in accordance with current technological recommendations (https://www.isa-poultry.com) and in the 18th week of age were moved to a private farm around Sarajevo, Bosnia and Herzegovina.

Were reared in cages holding. The hens were fed a standard diet supplied to feed hens. Testing the quality of eggs was carried out in the laboratories of Faculty of Agriculture in East Sarajevo. In this study, 30 eggs, selected by random sample method, were individually measured from three age periods (ALH a8) $0, \mathrm{ALH}_{2} 8$ and $\mathrm{ALH}$

In this study, are defined by the following indicators of the quality of eggs light line hybrid Isa Brown, such as egg weight (g), length of eggs (mm), width of the eggs (mm), egg shape index (\%), cleanliness of shell (points), the color of the shell (points) and the color of the yolk (point). 
The weight of eggs was measured on a technical scale with an accuracy of 0.01g. Length and width of the eggs were measured by simple accessories with an accuracy of $1 \mathrm{~mm}$ (caliper). Shape index egg is mathematically calculated as the width in\% length. The rating scales the color intensity is based on the subjective evaluation, described by points from 1 to 5 with the darkest color eggs received 5 points, a brightest point 1 are received. Cleanliness shell is visually assessed by points from 1 to 5 , from very dirty to clean completely. Rating yolk color intensity using the fan 15 of the brightest shades of yellow to dark orange (Roche Color Fan).

Based on the results determined the phenotypic correlation between egg mass and the basic characteristics of the properties quality of the eggs.

Phenotypic correlation coefficient is calculated using the formula by Hadživuković (1991). The strength of the correlation of phenotypic correlation is discussed on the basis of Roemer-Orphalove classification.

Coefficient of phenotypic correlation is calculated according to the form:

$$
\mathbf{r}_{\mathbf{x y}}=\frac{\sum x y-\frac{\left(\sum x\right)\left(\sum y\right)}{n}}{\sqrt{\left[\sum x^{2}-\frac{\left(\sum x\right)^{2}}{n}\right]\left[\sum y^{2}-\frac{\left(\sum y\right)^{2}}{n}\right]}} \cdot
$$

Examination of the statistical significance of the obtained coefficient of correlation was done by t-test through the form:

$$
\mathbf{t}=\mathbf{r}_{\mathbf{x y}} \mathbf{x} \frac{\sqrt{1-r^{2}}}{\sqrt{n-2}}
$$

\section{RESULTS AND DISCUSSION}

The above points to the fact that between the weight of the eggs and certain qualities of quality, they precisely condition one another. In this section, we will demonstrate and discuss phenotypic correlated between mass and egg quality traits. The table below shows the calculated correlation coefficients and the level of significance between egg quality traits and mass of eggs in three age periods $\left(\mathrm{ALH}_{20}, \mathrm{ALH}_{28}, \mathrm{ALH}_{48}\right)$.

Table 1 presents the correlation coefficients between the mass of eggs and egg quality traits, as well as the level of significance coefficients.

From the data of Table 1 we see that positive correlation coefficients between the mass and the length of eggs are statistically significant at the level $\mathrm{P}$ $<0.05$ and $\mathrm{P}<0.01$

In young laying hens at the beginning of use, to calculate the correlation coefficient was negative $\left(\mathrm{r}_{\mathrm{p}}=-0,023\right)$ and statistically significant at $\mathrm{P}<0.01$. 
Table 1. Correlation coefficients and the level of significance between the mass of eggs and egg quality traits

\begin{tabular}{|c|c|c|c|}
\hline Indicators & $\mathrm{ALH}$ & $\mathrm{r}_{\mathrm{p}}$ & $\mathrm{t}_{\text {exp. }}$ \\
\hline \multirow{3}{*}{ Egg lenght } & $\mathrm{ALH}_{20}$ & $-0,023^{* *}$ & 2,801 \\
& $\mathrm{ALH}_{28}$ & $0,405^{* *}$ & 9,603 \\
& $\mathrm{ALH}_{48}$ & $0,795^{* *}$ & 12,350 \\
\hline \multirow{3}{*}{ Width of the egg } & $\mathrm{ALH}_{20}$ & $0,638^{* *}$ & 9,871 \\
& $\mathrm{ALH}_{28}$ & $0,631^{* *}$ & 10,297 \\
& $\mathrm{ALH}_{48}$ & $0,670^{* *}$ & 11,325 \\
\hline \multirow{3}{*}{ Egg shape index } & $\mathrm{ALH}_{20}$ & $0,087 \mathrm{~ns}$ & 1,088 \\
& $\mathrm{ALH}_{28}$ & $0,113 \mathrm{~ns}$ & 1,445 \\
& $\mathrm{ALH}_{48}$ & $-0,012 \mathrm{~ns}$ & 0,176 \\
\hline \multirow{3}{*}{ Cleanliness egg } & $\mathrm{ALH}_{20}$ & $0,047 \mathrm{~ns}$ & 0,678 \\
& $\mathrm{ALH}_{28}$ & $-0,093 \mathrm{~ns}$ & 1,209 \\
& $\mathrm{ALH}_{48}$ & $-0.142 \mathrm{~ns}$ & 1,583 \\
\hline \multirow{3}{*}{ Colour of the shell } & $\mathrm{ALH}_{20}$ & $0,017 \mathrm{~ns}$ & 0,190 \\
& $\mathrm{ALH}_{28}$ & $-0,116 \mathrm{~ns}$ & 1,483 \\
& $\mathrm{ALH}_{48}$ & $-0,089 \mathrm{~ns}$ & 1,161 \\
\hline \multirow{3}{*}{ Colour of the yolk } & $\mathrm{ALH}_{20}$ & $0,657^{* *}$ & 11,279 \\
& $\mathrm{ALH}$ & $-0,032 \mathrm{~ns}$ & 0,289 \\
& $\mathrm{ALH}$ & $-0,016 \mathrm{~ns}$ & 0,168 \\
\hline
\end{tabular}

ns - P>0,05; * $\mathrm{P}<0,05 ; * *$ - $\mathrm{P}<0,01 ; * * *$ - $\mathrm{P}<0,001$

Statistically significant $(\mathrm{P}<0.01)$ correlation coefficients were determined between the mass of eggs and egg width, the strength of the connection medium to strong. The relationship between the mass of eggs and egg shape index was very weak in strength and not statistically confirmed $(\mathrm{P}>0.05)$ for all three age groups of laying hens. Calculate the coefficients in young laying hens were positive, and in the elderly negative.

Between the weight of the egg and the cleanliness of the shell in young layer hens $\left(\mathrm{ALH}_{20}\right)$ the correlation coefficient was positive $\left(\mathrm{r}_{\mathrm{p}}=0,047\right)$. With the age of the hens, the calculated correlation coefficients get a negative sign, the connections become slightly stronger, but are still very weak on the scale. In all three periods showed no statistically significant differences. Regarding the direction and strength of the connection, almost the same situation is found between the mass of eggs and the color of the shell.

In addition, Table 1 shows a positive correlation coefficient between egg yolk and yolk color at the first sampling $\left(\mathrm{ALH}_{20}\right)$, which was $\mathrm{r}_{\mathrm{p}}=0,657$ (strong correlation) and was statistically significant at $\mathrm{P}<0.01$. For maximum egg production and mid-production cycle to calculate coefficients were negative, the strength of the weak and insignificant $(\mathrm{P}>0.05)$.

Similar results, the correlation coefficients between the weight of the eggs and the quality characteristics were determined by Mitrovic et al. (2010), while 
Đekić et al. (2008) determined a statistically significant correlation coefficient (P $<0.05)$ between egg mass and egg shape index $\left(r_{p}=0,772\right)$.

According to Rajičić et al. (2008), Shi et al. (2009), the importance of weight (weight) of eggs is also reflected in the fact that it significantly influences other quality properties of eggs, such as the index of egg shape, purity of the shell and color of the shell. This fact was confirmed by calculating the correlation coefficient between the weight of eggs and the abovementioned properties.

\section{CONCLUSIONS}

Based on the results of the above mentioned indicators we can conclude the following:

Between the weight of the eggs and the length, that is, the width of the eggs, statistically significant correlation coefficients were found during all three test periods. $(\mathrm{P}<0.01)$. The same is established and the correlation relative masses of eggs and yolk color in the first period of production $\left(\mathrm{ALH}_{20}\right)$. On the other traits of egg quality, with different age hens, egg weight had no statistically significant effect $(\mathrm{P}>0.05)$.

Viewed as a whole, it can be concluded that the analyzed commercially flock light line hybrid Isa Brown, grown at the poultry farm private households (B\&H, RS), in most of the traits quality eggs achieved satisfactory results.

\section{REFERENCES}

Campo JL, gil MG, Dávila SG (2007): Differences among white-, tinted-, and brown-egg laying hens for incidence of eggs laid on the floor and for oviposition time. Arch Geflügelkd, 71: 105-109.

Đekić V., Milivojević J., Staletić M. 2008. Influence of hens genotype and age on tje shape index of eggs. 43rd Croatian and 3rd International Symposium on Agriculture, Opatija, Croatia (842-844).

Hadživuković S. 1991. Statistical methods with application in agricultural and biological research, p. 461, Novi Sad.

https://www.isa-poultry.com

Mitrovic S., Pandurevic T., Milic V., Djekic V., Djermanovic V. (2010): Weight and egg quality correlation relationship on different age laying hens. International Journal of Food, Agriculture \& Environment - JFAE. Publisher: WFL, ISSN:1459-0263, vol. 8, Issue 3\&4, p. 580-583.

Pavlovski Z. 1988. Uticaj načina proizvodnje i uslova tržišta na konzumni kvalitet jaja. Peradarstvo, 11-12, 128-133.

Rajičić V., Mitrović S., Tolimir N., Perić L. 2008. Uticaj genotipa i uzrasta nosilja na kvalitet ljuske jajeta. Savremena poljoprivreda, vol. 57, 1-2 (2008), strana 201206, Novi Sad.

Schwaegele F. 2001. Egg quality assurance system under aspect of the EU requirementsand demand of the consumer, IX European Symposium on the Quality of eggs and eggs products.

Shi S.R., Wang K.H., Yang H.M. 2009. Egg weight affects some quality traits of chicken eggs. Journal of Food, Agriculture \& Enviroment, Vol. 7(2):432-434. 
Tolimir N., Perić L., Đukić-Stojčić M., Milošević N. 2008. Uticaj hibrida i uzrasta kokoši nosilja na kvalitet konzumnih jaja. Biotechnology in Animal Husbandry 24 (spec. Issue), p 245-252, Belgrade-Zemun.

Van den Brand H., Parmentier H. K., Kemp B. 2004. Effect of housing system and age of laying hens on egg characteristics“, Br. Poul Sci. 45: 745-752.

Zemková L', Simeonovová J, Lichovníková M, Somerlíková K. 2007. The effects of housing systems and age of hens on the weight and cholesterol concentration of the egg. Czech J. Anim. Sci., 52: 110-115.

Zita, L., Tůmová E., Stolc L. 2009. Effects of genotype, age nd their interaction on equlity in brown-egg laying hens. Acta Vet. Brno, 78: 85-91 